\title{
Pemodelan Torque Vectoring Sebagai Upaya Untuk Meningkatkan Stabilitas Pengendalian Mobil Listrik
}

\author{
Roche Alimin $^{1 *}$, Ian Hardianto Siahaan ${ }^{2}$, Andre Saputra ${ }^{3}$ \\ 1,2,3 Program Studi Teknik Mesin, Fakultas Teknologi Industri, Universitas Kristen Petra \\ Jl. Siwalankerto 121-131, Surabaya 60236, Indonesia \\ * Penulis korespondensi; E-mail: ralimin@petra.ac.id
}

\begin{abstract}
ABSTRAK
Produsen otomotif saat ini sedang gencar-gencarnya melakukan pengembangan mobil listrik. Selain karena mobil listrik lebih mudah untuk diarahkan kepada penggunaan energi yang lebih ramah lingkungan, mobil listrik juga lebih fleksibel di dalam penerapan teknologi kontrol yang lebih mutakhir. Saat ini salah satu sistem kontrol yang tersedia dan dikembangkan pada mobil listrik adalah Torque Vectoring. Pada penelitian ini dilakukan pengembangan algoritma sistem Torque Vectoring beserta sistem kontrolnya melalui pemodelan dan simulasi MATLAB-Simulink. Metode kontrol yang digunakan adalah kontroler PID. Variabel yang diukur untuk melihat keefektivitas sistem Torque Vectoring adalah yaw rate, sudut kemudi, sudut sideslip, traksi pada setiap ban, percepatan longitudinal dan lateral, kecepatan longitudinal, slip longitudinal di setiap ban, dan torsi output di setiap roda. Dari penelitian ini dapat disimpulkan bahwa algoritma sistem Torque Vectoring yang dikembangkan mampu meningkatkan stabilitas pengendalian mobil listrik. Sistem Torque Vectoring tersebut mampu beroperasi pada berbagai kondisi jalan dan manuver mobil, sehingga mobil dengan sistem Torque Vectoring lebih dapat dikendalikan dan stabil jika dibandingkan dengan mobil tanpa sistem Torque Vectoring.
\end{abstract}

Kata kunci: Dinamika kendaraan, torque vectoring, kendaraan listrik, distribusi torsi, PID.

\begin{abstract}
Automotive manufacturers are currently intensively developing electric cars. Apart from the fact that electric cars are easier to direct towards the use of more environmentally friendly energy, electric cars are also more flexible in the implementation of more advanced control technologies. Currently, one of the control systems available and developed in electric cars is Torque Vectoring. In this research study, the development of the Torque Vectoring system algorithm and its control system was carried out through MATLAB-Simulink modeling and simulation. The control method used is the PID controller. The variables measured to see the effectiveness of the Torque Vectoring system are yaw rate, steering angle, sideslip angle, traction on each tire, longitudinal and lateral acceleration, longitudinal speed, longitudinal slip on each tire, and output torque on each wheel. From this research study, it is concluded that the developed Torque Vectoring system algorithm is able to improve the stability of electric car control. The Torque Vectoring system is capable of operating in various road conditions and car maneuvers, so a car with a Torque Vectoring system is more controllable and stable than a car without a Torque Vectoring system.
\end{abstract}

Keywords: Vehicle dynamics, torque vectoring, electric car, torque distribution, PID.

\section{PENDAHULUAN}

Pesatnya perkembangan mobil listrik membuat banyak produsen otomotif berlomba mengembangkan teknologi mobil listrik mereka sendiri. Dari sisi pengaturan performa, mobil listrik lebih banyak menyediakan fleksibilitas daripada mobil konvensional sehingga implementasi kontrol yang lebih mutakhir menjadi lebih memungkinkan. Perkembangan teknologi mobil listrik dalam beberapa tahun terakhir ini begitu pesat sejalan dengan pertumbuhan produksi mobil listrik. Di tahun 2018, jumlah mobil listrik global melebihi 5,1 juta unit, lebih banyak 2 juta unit jika dibandingkan dengan tahun sebelumnya [1].

Mobil listrik memiliki kelebihan bila dibandingkan mobil konvensional yang menggunakan bahan bakar fosil. Mobil listrik menyediakan fleksibilitas dan kontrol yang lebih baik [2]. Dengan kelebihan ini maka kontrol dan peningkatan performa mobil listrik dapat dilakukan dengan lebih mudah tanpa perlu menambahkan komponen mekanis tertentu pada mobil. 
Salah satu sistem kontrol yang tersedia dan dikembangkan pada mobil listrik saat ini adalah Torque Vectoring. Istilah Torque Vectoring pertama kali diperkenalkan oleh Ricardo PLC, sebuah perusahaan pengembang teknologi dalam bidang otomotif pada SAE Technical Paper 2004-01-0863. Pada saat itu teknologi Torque Vectoring dikembangkan untuk diferensial mobil 4WD, yaitu untuk mendistribusikan torsi keluaran dari mesin sesuai dengan kondisi dinamika kendaraan. Sejak saat itu banyak pabrikan otomotif seperti Toyota, Ford, Nissan dan lainnya mulai mengembangkan sistem Torque Vectoring untuk diterapkan pada mobil-mobil mereka. Prinsip dari sistem pendistribusian torsi pada mobil sudah dikembangkan dan dipatenkan dengan nomor paten US5376868A pada tahun 1994. Saat ini sistem Torque Vectoring digunakan pada mobil listrik untuk mengontrol keluaran torsi dan putaran dari setiap motor listrik sesuai dengan dinamika kendaraan sehingga bisa memaksimalkan traksi pada setiap roda mobil. Ini akan meningkatkan performa kendaraan ketika menikung dan dinamika lateral kendaraan tanpa memberikan pengaruh negatif terhadap performa dinamika longitudinal kendaraan [3]. Pada akhirnya sistem Torque Vectoring ini akan menggantikan dan memadukan sistem ESP (Electronic Stability Program) dan TCS (Traction Control System).

Gambar 1 menunjukan cara dari sistem Torque Vectoring untuk mobil RWD. Prinsip dari Torque Vectoring tetap sama untuk mobil FWD dan AWD. Ketika torsi yang berbeda didistribusikan ke masingmasing roda penggerak, maka terdapat perbedaan gaya longitudinal pada roda penggerak. Perbedaan gaya longitudinal ini akan menghasilkan momen yaw tambahan, $\Delta M_{z}$, yang membantu mobil untuk menikung.

$$
\Delta M_{z}=\frac{w}{2}\left(F_{x_{r}}-F_{x_{l}}\right)
$$

dengan $F_{x_{r}}$ adalah gaya longitudinal pada roda penggerak kanan, $F_{x_{l}}$ adalah gaya longitudinal pada roda penggerak kiri, dan $w$ adalah jarak dari roda penggerak kiri ke roda penggerak kanan.

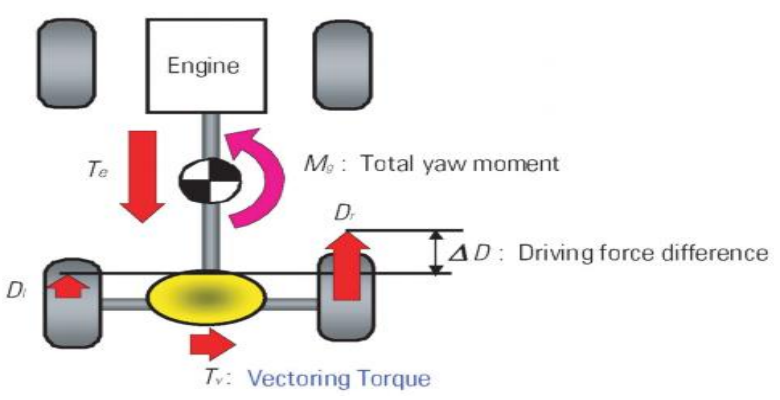

Gambar 1. Definisi Torque Vectoring. Sumber: Stoop (2014, p. 12)

Efek dari sistem Torque Vectoring dapat dilihat pada Gambar 2. Dengan distribusi torsi yang berbeda ke setiap roda maka roda bagian luar dapat memaksimalkan potensi gaya pada roda sampai pada batasnya (sesuai dengan friction ellipse) dan bisa mengurangi beban pada roda bagian dalam ketika menikung (juga sesuai dengan friction ellipse).

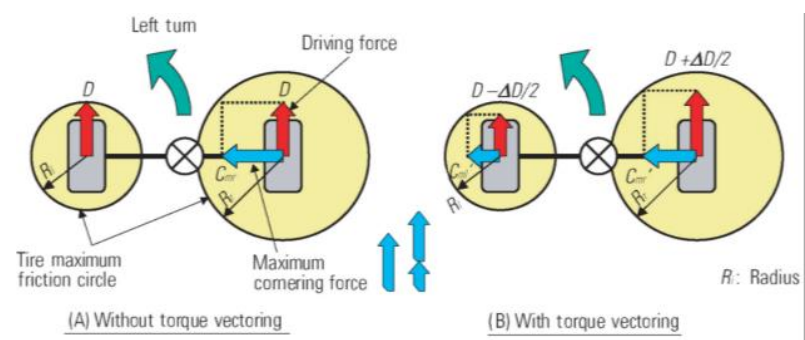

Gambar 2. Efek dari Torque Vectoring [4]

Implementasi sistem Torque Vectoring pada mobil listrik akan lebih mudah apabila mobil listrik tersebut memiliki 2 atau 4 motor listrik yang menggerakkan roda secara independen (in-wheel motor). Dengan demikian torsi positif dan negatif dapat dihasilkan secara langsung dari motor listrik sehingga tidak memerlukan diferensial seperti yang biasa ditemui pada mobil konvensional.

Isu utama dari perancangan sistem Torque Vectoring ini adalah ada banyak pendekatan dan cara untuk mengoptimalkan distribusi torsi pada setiap roda penggerak [5]. Oleh karena itu, untuk saat ini belum ada kesepakatan umum mengenai bagaimana cara yang optimal untuk memanfaatkan potensi penuh dari sistem ini [6][7]. Berikut ini adalah penelitian-penelitian terdahulu. Ada beragam pemodelan dan metode kontrol yang digunakan didalam memodelkan sistem Torque Vectoring ini. Untuk metode kontrol ada yang menggunakan Fuzzy Logic [8], Linear Parameter-Varying [9], Model Predictive Control [10], Proportional Integral Derivative [11], dan Sliding Mode Controller [12]. Model dinamika kendaraan yang digunakan bervariasi, mulai dari $2 D O F$ sampai dengan $14 D O F$. Model ban yang digunakan juga bervariasi, seperti model ban Pacejka, Dugoff dan Burckhardt.

Kendala-kendala yang terdapat pada penelitian ini adalah adanya algoritma kontrol yang rumit sehingga beban dalam melakukan proses komputasi pada mikrokontroler menjadi lebih berat. Beberapa penelitian terdahulu juga kurang mempertimbangkan batasan-batasan fisik seperti torsi keluaran maksimum dari motor listrik. Sampai dengan saat ini masih belum ada kesepakatan umum terkait dengan bagaimana memanfaatkan potensi penuh dari sistem Torque Vectoring ini [13][14].

Penelitian ini bertujuan memodelkan secara matematis sistem Torque Vectoring dan melihat efektifitas sistem Torque Vectoring dalam meningkatkan stabilitas pengendalian mobil listrik jika dibandingkan dengan mobil listrik tanpa sistem Torque Vectoring. Hasil dari penelitian ini diharapkan bermanfaat untuk mengembangkan sistem Torque Vectoring yang simpel dan efektif, serta dapat diterapkan pada mobil listrik dengan berbagai konfigurasi (FWD, RWD ataupun AWD). 


\section{METODOLOGI}

Penelitian ini dimulai dengan menentukan parameter untuk memodelkan dinamika kendaraan, sistem Torque Vectoring dan sistem kontrolnya. Setelah parameter didapatkan maka dilakukan pemodelan dinamika kendaraan, sistem Torque Vectoring dan sistem kontrolnya. Kemudian diverifikasi apakah model mengeluarkan nilai yang seharusnya ketika melakukan perhitungan. Setelah hasilnya sesuai maka simulasi sistem dapat dilakukan. Sistem Torque Vectoring disimulasikan di MATLAB-Simulink dengan manuver double lane change dengan kecepatan entry $80 \mathrm{~km} / \mathrm{jam}$. Prosedur double lane change adalah tes untuk mensimulasikan manuver darurat untuk menentukan dinamika pengendalian transien kendaraan (vehicle transient handling dynamics). Tes ini umum digunakan karena berhubungan dengan mobil yang lebih aman dan terkontrol adalah ketika mobil didorong sampai ke batas pengendaliannya, ada peluang yang lebih besar bagi pengemudi untuk menghindari kecelakaan [15]. Dimensi jalur dapat dilihat pada Gambar 3.

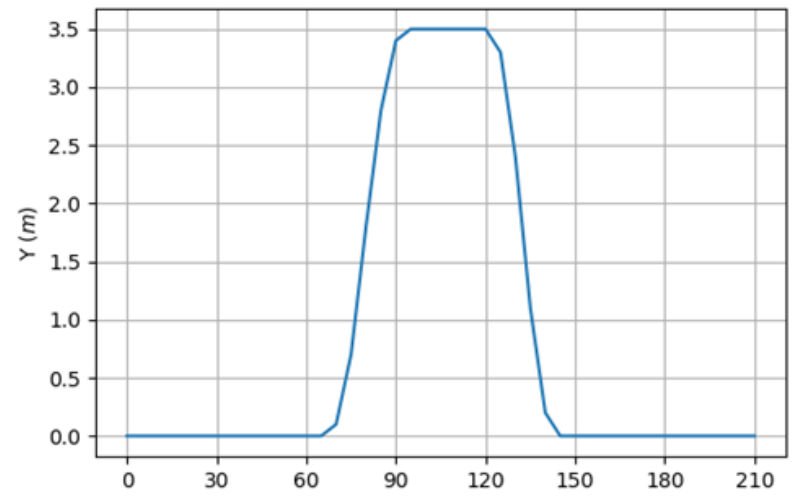

Gambar 3. Dimensi jalur double lane change, dalam satuan meter

Dari hasil simulasi akan diamati apakah sistem stabil dan nilai aktual mobil mendekati nilai referensi dari perhitungan. Jika belum stabil dan belum sesuai maka akan dilakukan proses tuning parameter ulang pada tahap verifikasi model sampai stabil dan nilai sudah mendekati nilai referensi. Data hasil simulasi akan dianalisa keefektivitasan sistem Torque Vectoring dalam meningkatkan stabilitas pengendalian mobil listrik. Untuk lebih detailnya dapat dilihat pada diagram alir pada Gambar 4.

Adapun lingkup pemodelan sistem Torque Vectoring yang dilakukan pada penelitian ini adalah sebagai berikut: Pemodelan sistem Torque Vectoring dibatasi untuk mobil listrik independent wheel drive dengan masing-masing in-wheel motor-nya pada keempat rodanya. Dimensi mobil dan ban mengikuti spesifikasi dan dimensi model yang telah ditetapkan/ default. Simulasi berfokus pada pengujian sistem pada steering manuver dan akselerasi. Gerakan roll dan pitch mobil serta gaya-gaya aerodinamis pada bodi mobil diabaikan. Torsi maksimum di setiap motor sebesar $1500 \mathrm{Nm}$. Pada pengujian akselerasi torsi dibatasi menjadi $1200 \mathrm{Nm}$ untuk koefisien gesek ban dengan jalan $\mu=0,6$ dan $800 \mathrm{Nm}$ untuk $\mu=0,3$.

Variabel yang akan menjadi indikator keefektifan Torque Vectoring pada penelitian ini adalah yaw rate, yaitu nilai yaw rate pada mobil $\dot{\psi}$ yang dibandingkan dengan nilai yaw rate referensi $\dot{\psi}_{\text {ref }}$, besar sudut kemudi $\delta$, slip longitudinal di setiap ban dan torsi output di setiap roda. Kesemuaannya dibandingkan antara kondisi dengan Torque Vectoring dan tanpa Torque Vectoring.

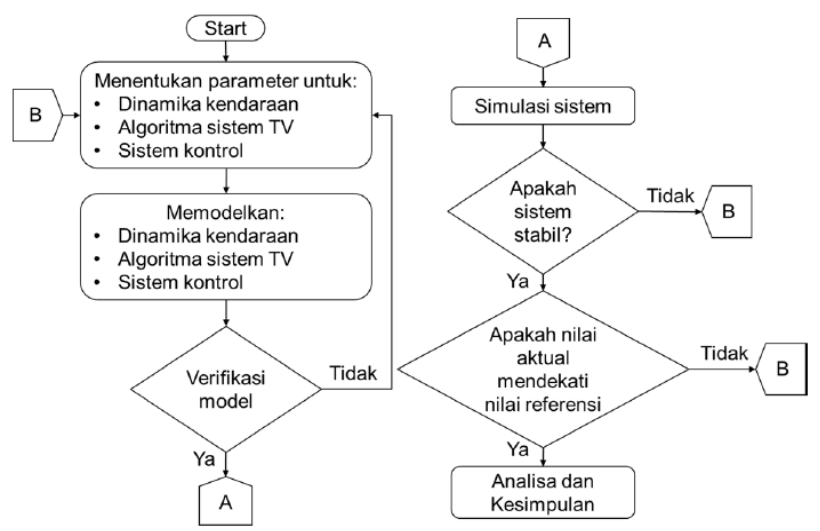

Gambar 4. Diagram alir metodologi

\section{Pemodelan Dinamika Kendaraan}

Model vehicle handling memiliki 7 DOF, yang terdiri dari bodi mobil memiliki 3 DOF (longitudinal, lateral, yaw) dan 4 DOF berupa putaran dari masingmasing roda [16]. Free body diagram dari model vehicle handling dapat dilihat pada Gambar 5.

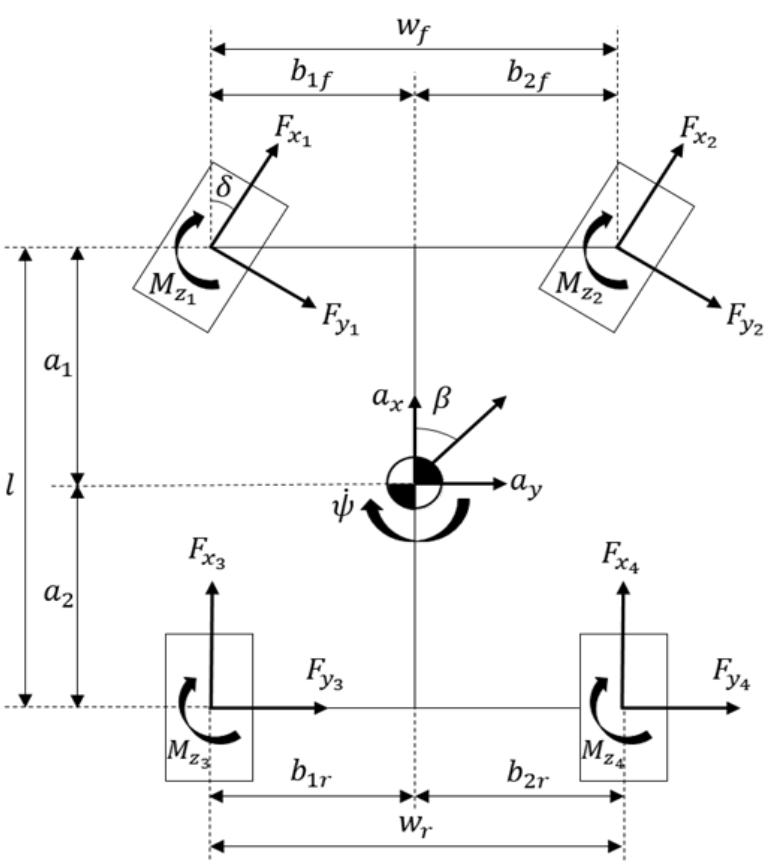

Gambar 5. Free body diagram dari model vehicle handling 
Nilai sudut kemudi $\delta$ diperoleh dari rata-rata sudut belok roda depan kiri $\delta_{1}$ dan sudut belok roda depan kanan $\delta_{2}$.

$$
\delta=\frac{\delta_{1}+\delta_{2}}{2}
$$

Ada beberapa pemodelan yang dilakukan pada penelitian ini, antara lain: pemodelan vehicle handling, pemodelan gerak longitudinal kendaraan, pemodelan gerak lateral kendaraan, pemodelan gerak yaw kendaraan, pemodelan gerak berputar pada roda kendaraan, pemodelan gerak sideslip tiap roda dan pemodelan gerak slip longitudinal tiap roda. Namun demikian pada makalah ini hanya akan dibahas untuk gerak slip longitudinal tiap roda. Gambar 6 adalah block diagram dari model slip longitudinal pada tiap roda tersebut.
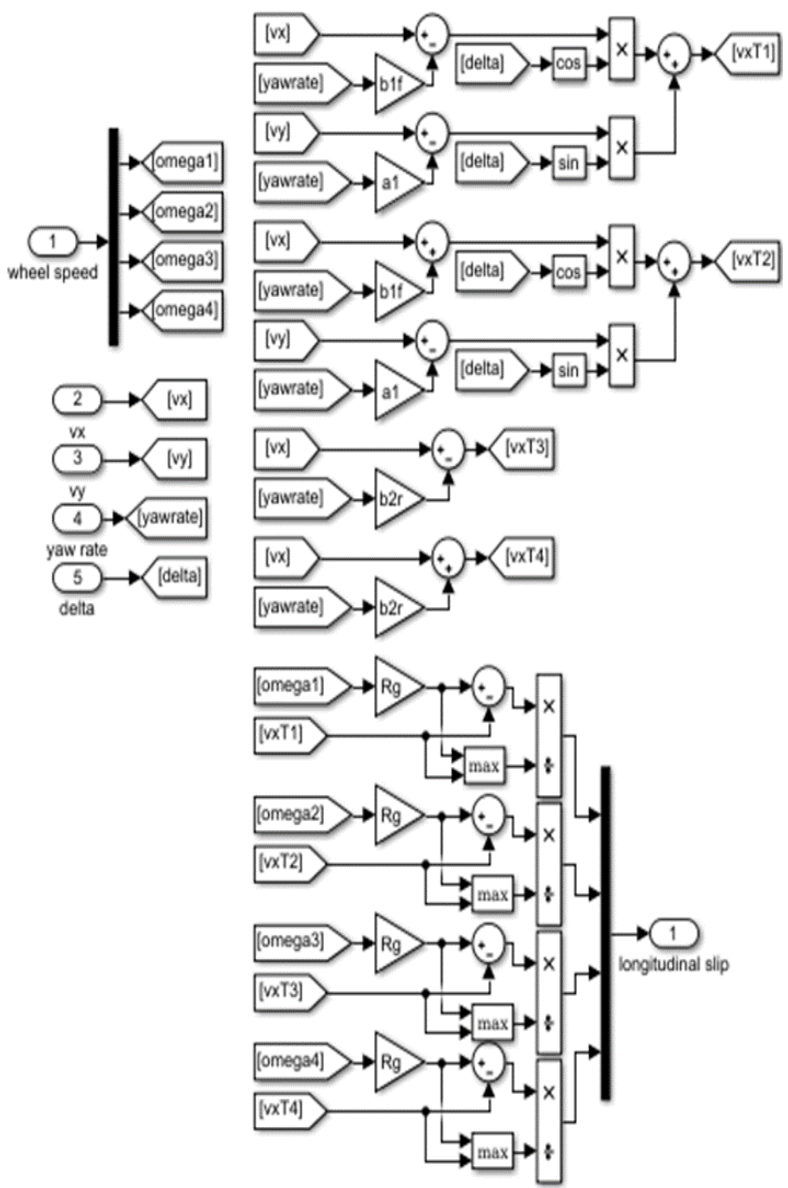

Gambar 6. Block diagram dari model slip longitudinal pada tiap roda

\section{Pemodelan Sistem Torque Vectoring}

Model sistem Torque Vectoring ini terdiri dari 3 bagian besar, yaitu model reference value generator, model kontrol yaw rate, dan model kontrol distribusi torsi ke roda. Pemodelan sistem Torque Vectoring dilakukan dengan menggunakan software MATLABSimulink, dengan plant yang didapat dari model dinamika kendaraan. Skema simulasiya dapat dilihat pada Gambar 7.

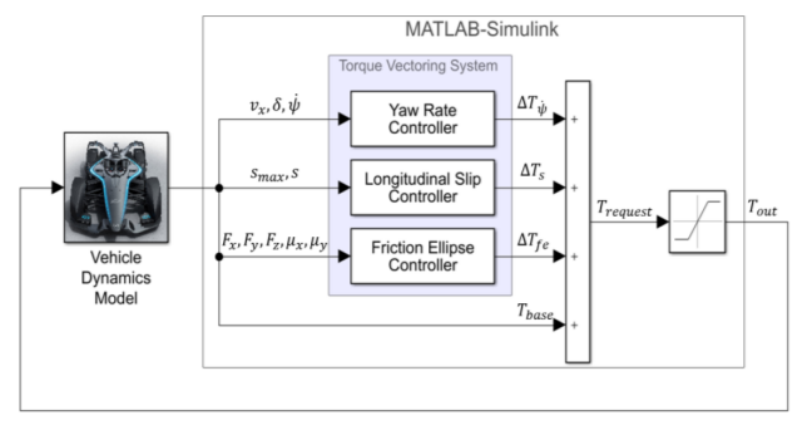

Gambar 7. Skema simulasi sistem Torque Vectoring pada Simulink

Kontroler yaw rate berfungsi untuk mengendalikan mobil ketika dalam kondisi menikung. Kontroler longitudinal slip berfungsi untuk mengendalikan mobil ketika dalam kondisi akselerasi. Sedangkan kontroler friction ellipse berfungsi untuk mengendalikan mobil pada semua kondisi manuver mobil.

\section{HASIL DAN PEMBAHASAN}

Dari grafik yaw rate pada Gambar 8 terlihat bahwa mobil yang dilengkapi dengan sistem Torque Vectoring (TV ON) dapat mendekati nilai desired yaw rate yang merupakan yaw rate yang diinginkan oleh pengemudi berdasarkan kecepatan dan sudut kemudi. Sedangkan apabila mobil tidak dilengkapi dengan sistem Torque Vectoring (TV OFF) maka mobil cenderung menjadi tidak stabil. Hal ini terjadi khususnya pada permukaan jalan licin $(\mu=0,3)$. Dan pada permukaan jalan yang lebih kasar $(\mu=0,6$ dan $\mu=0,9)$ respon mobil masih dapat mengikuti permintaan pengemudi tetapi lebih lambat.

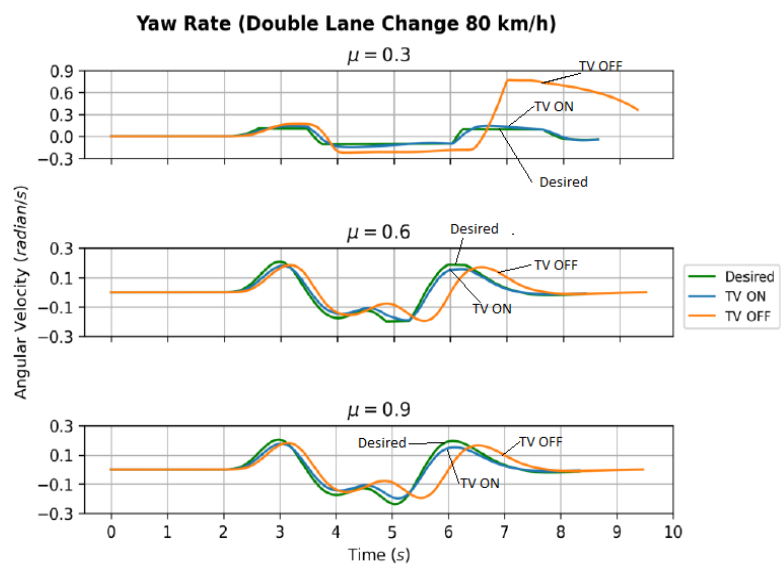

Gambar 8. Grafik yaw rate mobil pada manuver double lane change dengan permukaan jalan $(\mu)$ yang berbeda

Dari grafik sudut kemudi pada Gambar 9 terlihat bahwa TV ON dapat mengurangi input sudut kemudi dari pengemudi. Ketika jalan licin, koreksi sudut kemudi yang diberikan pengemudi untuk menjaga mobil tetap pada jalur jauh menjadi lebih kecil bila dibandingkan dengan TV OFF. Sudut kemudi yang dimaksud adalah sudut rata-rata dari sudut belok roda kiri depan dan roda kanan depan. 


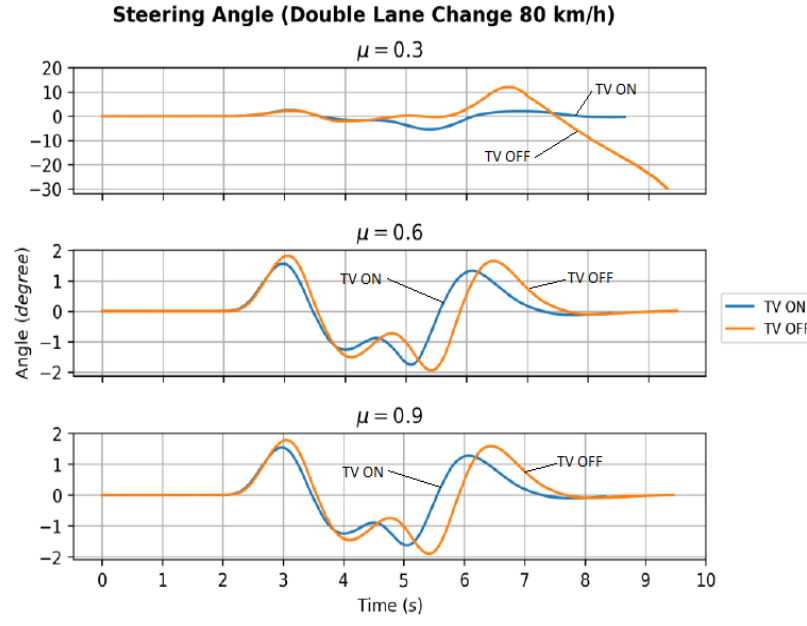

Gambar 9. Grafik sudut kemudi mobil pada manuver double lane change dengan permukaan jalan $(\mu)$ yang berbeda

Dari grafik slip longitudinal pada Gambar 10 terlihat bahwa TV ON dapat menjaga slip longitudinal di setiap roda untuk tetap di bawah batas slip maksimum senilai 0,15. Perbedaan yang signifikan terlihat pada kondisi jalan licin $(\mu=0,3)$. Pada kondisi ini slip longitudinal pada TV ON dapat ditekan di bawah 0,15 , dan ketika TV OFF nilai slip menjadi sangat besar. Sedangkan pada kondisi jalan yang lebih kasar $(\mu=0,6$ dan $\mu=0,9)$ terlihat bahwa TV ON dan TV OFF tidak terjadi slip longitudinal yang cukup signifikan.

Performa yaw rate (error yaw rate) yang dihasilkan sejalan dengan hasil penelitian Fricano [3] yang menyatakan bahwa dengan Torque Vectoring, kendaraan menunjukkan performa dinamika lateral yang baik tanpa memberikan pengaruh negatif terhadap performa dinamika longitudinal kendaraan [3].

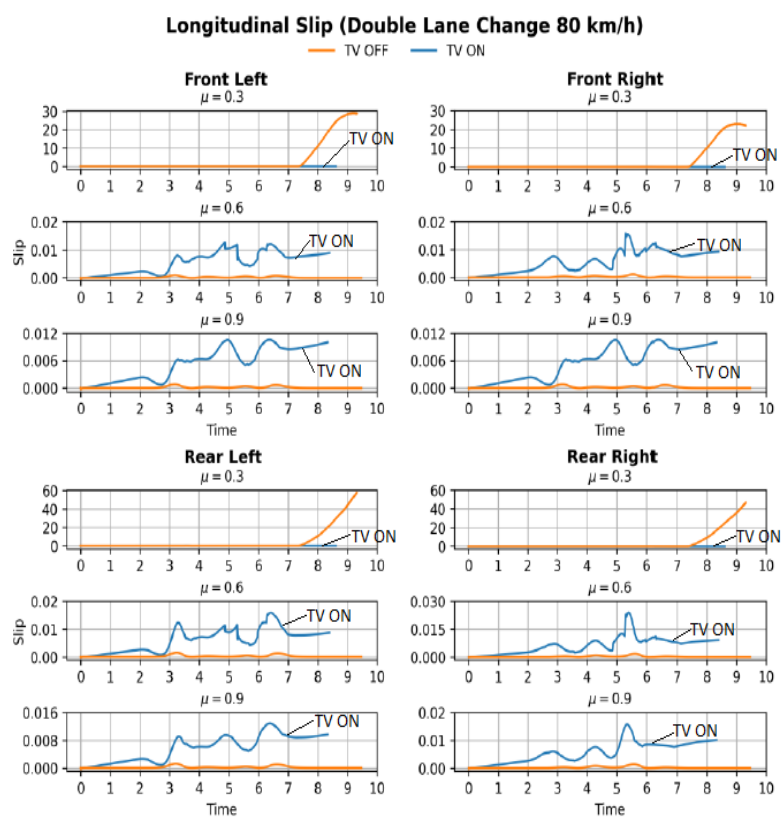

Gambar 10. Grafik slip longitudinal pada setiap roda pada manuver double lane change dengan permukaan jalan $(\mu)$ yang berbeda
Untuk besar nilai slip longitudinal TV ON di setiap roda pada kondisi jalan licin yang lebih rinci dapat dilihat pada Gambar 11.

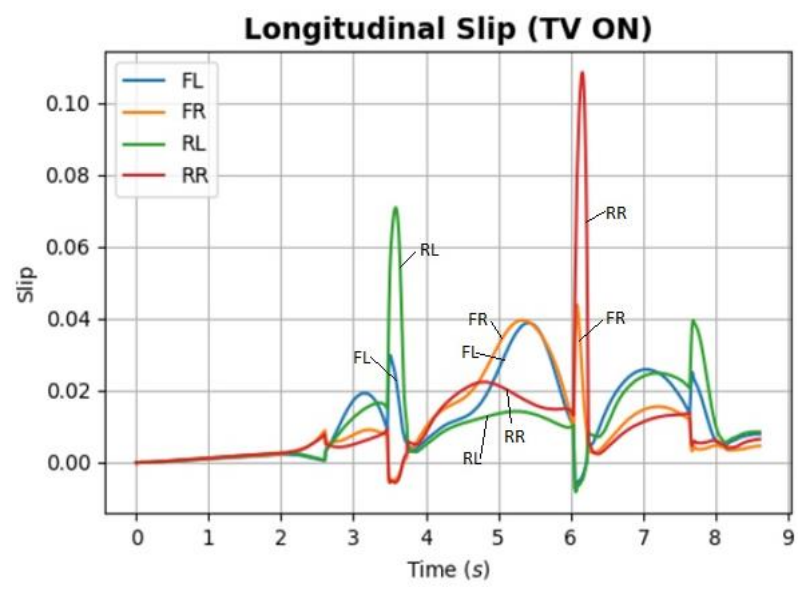

Gambar 11. Grafik slip longitudinal TV ON pada setiap roda pada kondisi jalan licin $(\mu=0,3)$

Grafik pada Gambar 12 memperlihatkan bahwa torsi output TV OFF lebih besar daripada TV ON. Namun, di $\mathrm{t}=7 \mathrm{~s}$, terjadi osilasi nilai torsi output. Hal ini dapat dibandingkan dengan grafik slip longitudinal TV OFF pada Gambar 10, dimana pada waktu yang sama, mobil mengalami kenaikan nilai slip yang signifikan. Ini menunjukan bahwa torsi dari motor listrik tidak dapat disalurkan dengan baik oleh ban ke jalan. Osilasi pada torsi output motor dapat menyebabkan motor mengalami wear yang lebih besar, yang berakibat pada umur motor yang berkurang. Hal ini tentu bisa dihindari dengan penggunaan sistem Torque Vectoring, dimana torsi dapat dikontrol untuk setiap motor sehingga dapat memaksimalkan traksi.
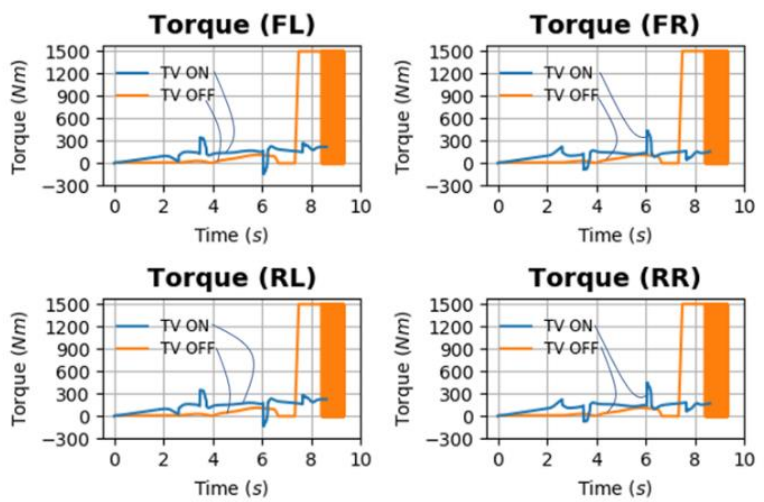

Gambar 12. Grafik torsi output TV ON pada setiap roda pada kondisi jalan licin $(\mu=0,3)$

Gambar 13 memperlihatkan nilai torsi ban kiri berbanding terbalik dengan nilai torsi ban kanan. Hal ini menunjukan bahwa sistem Torque Vectoring dapat mengontrol torsi output setiap motor sehingga dapat menghasilkan perbedaan nilai torsi motor antara roda kiri dan 
kanan, yang pada akhirnya membantu mobil dalam menghasilkan momen yaw bagi mobil untuk menikung.

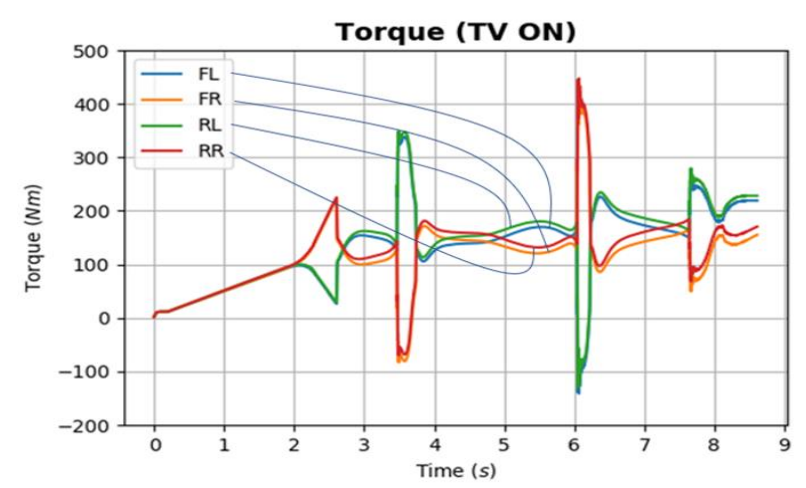

Gambar 13. Grafik torsi output TV ON pada kondisi jalan licin $(\mu=0,3)$

Untuk jalan yang lebih kasar $(\mu=0,6$ dan $\mu=$ $0,9)$ masing-masing grafik torsi output memperlihatkan trend yang senada, yaitu torsi output pada TV ON lebih besar daripada TV OFF. Hal ini sudah sewajarnya karena sistem Torque Vectoring mengontrol manuver mobil dengan mengatur torsi output di setiap motor. Hal ini diperlihatkan pada Gambar 14 dan 15 bahwa torsi roda kiri depan sama dengan torsi roda kiri belakang. Begitu pula dengan kedua roda yang di sebelah kanan.
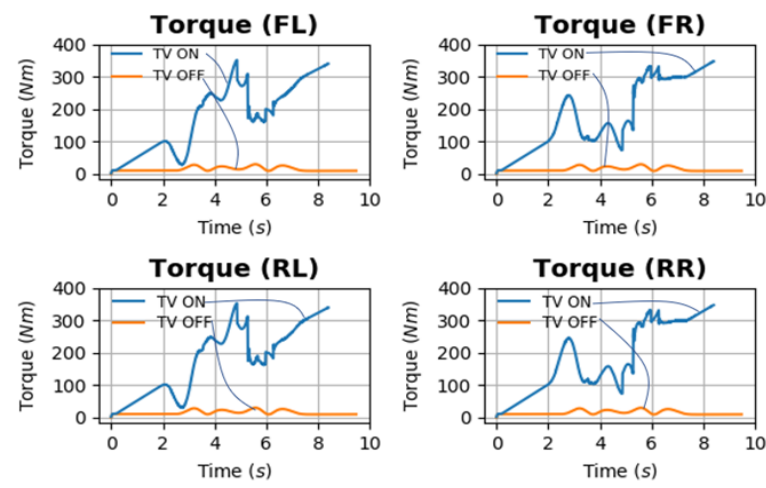

Gambar 14. Grafik torsi output TV ON pada setiap roda pada kondisi jalan licin $(\mu=0,6)$
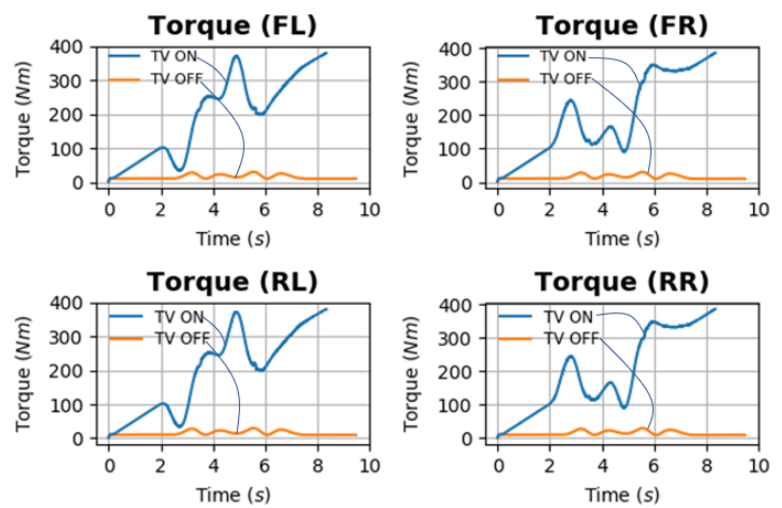

Gambar 15. Grafik torsi output TV ON pada setiap roda pada kondisi jalan licin $(\mu=0,9)$

\section{KESIMPULAN}

Dari hasil pemodelan dan simulasi dapat disimpulkan bahwa sistem Torque Vectoring mampu meningkatkan kestabilan dan pengendalian mobil listrik, khususnya ketika kondisi jalan licin. Sistem Torque Vectoring juga mampu mengurangi input dari pengemudi untuk mengoreksi posisi mobil untuk kembali ke jalur yang diinginkan pengemudi.

\section{DAFTAR PUSTAKA}

[1]. IEA, Global EV outlook, 2019, Scaling-up Transation to Electric Mobility, http://iea.org. [Accessed on September 9th 2019]

[2]. Wong, A., Kasinathan, D., Khajepour, A., Chen, S.K., Litkouhi, B., 2016, "Integrated Torque Vectoring and Power Management Framework for Electric Vehicles", Control Engineering Practice, 48, pp. 22-36.

[3]. Fricano, A., 2019, "Design of Torque Vectoring System for Formula SAE Electric Vehicle", Master's Thesis, Mechanical Engineering Department, Politecnico di Torino, Italia.

[4]. Stoop, A., 2014, "Design and Implementation of Torque Vectoring for the Forze Racing Car: In Collaboration with the Forze Hydrogen Racing Team”, Master's Thesis, Mechanical Engineering Department, Delft University of Technology, Belanda.

[5]. Ghezzi, M. K., 2017, "Control of a Four In-Wheel Motor Drive Electric Vehicle", Master's Thesis, Industrial Engineering Department, Polytechnic University of Catalonia, Spanyol.

[6]. Crolla, D. A., Cao, D., 2012, "The Impact of Hybrid and Electric Powertrains on Vehicle Dynamics, Control Systems and Energy Regeneration", Vehicle System Dynamics, 50(sup1), 95109. https://doi.org/10.1080/00423114.2012.676651

[7]. Goggia, T., Sorniotti, A., De Novellis, L., Ferrara, A., Gruber, P., Theunissen, J., Steenbeke, D., Knauder, B., \& Zehetner, J., 2015, "Integral Sliding Mode for The Torque-Vectoring Control of Fully Electric Vehicles: Theoretical Design and Experimental Assessment", IEEE Transactions on Vehicular Technology, 64(5), pp. 17011715.

[8]. Jalali, K., Uchida, T., Lambert, S., McPhee, J., 2013, "Development of an Advanced Torque Vectoring Control System for an Electric Vehicle with In-Wheel Motors using Soft Computing Techniques", SAE International Journal of Alternative Powertrains, 2(2), pp. 2013-01-0698.

[9]. Kaiser, G., Holzmann, F., Chretien, B., Korte, M., Werner, H., 2011, "Torque Vectoring with a Feedback and Feed Forward Controller -Applied to a Through The Road Hybrid Electric Vehicle", IEEE Intelligent Vehicles Symposium (IV), IV, pp. 448-453. 
[10]. Ren, B., Chen, H., Zhao, H., \& Yuan, L., 2015, "MPC-Based Yaw Stability Control in In-WheelMotored EV via Active Front Steering and Motor Torque Distribution", Mechatronics, 38, pp. 103114.

[11]. Antunes, J., Antunes, A., Outeiro, P., Cardeira, C., \& Oliveira, P., 2019, "Testing of a Torque Vectoring Controller for a Formula Student Prototype", Robotics and Autonomous Systems, 113 , pp. 56-62.

[12]. Ding, S., Liu, L., \& Zheng, W. X., 2017, "Sliding Mode Direct Yaw-Moment Control Design for In-Wheel Electric Vehicles", IEEE Transactions on Industrial Electronics, 64(8), pp. 6752-6762.

[13]. Crolla, D. A., \& Cao, D., 2012, "The Impact Of Hybrid and Electric Powertrains on Vehicle Dynamics, Control Systems and Energy Regeneration", Vehicle System Dynamics, 50(1), pp. 95-109.
[14]. Goggia, T., Sorniotti, A., De Novellis, L., Ferrara, A., Gruber, P., Theunissen, J., Steenbeke, D., Knauder, B., Zehetner, J., 2015, "Integral Sliding Mode for The Torque-Vectoring Control of Fully Electric Vehicles: Theoretical Design and Experimental Assessment", IEEE Transactions on Vehicular Technology, 64(5), pp. 1701-1715.

[15]. Peng, Y., Yang, X., 2012, "Comparison of Various Double-Lane Change Manoeuvre Specifications", Vehicle System Dynamics, 50(7), pp. 1157-1171.

[16]. Setiawan, J. D., Safarudin, M., Singh, A., 2009, "Modeling, Simulation and Validation of 14 DOF Full Vehicle Model", International Conference on Instrumentation, Communication, Information Technology, and Biomedical Engineering, IEEE, Bandung, Indonesia. 